\title{
Toward Stratified Treatments for Bipolar Disorders
}

Gregor Hasler, M.D. ${ }^{1}$, Andreas Wolf, M.D. ${ }^{1}$

${ }^{1}$ Department of Molecular Psychiatry, University Hospital of Psychiatry, University of Bern, Switzerland

Corresponding author:

Gregor Hasler

University Hospital of Psychiatry, University of Bern

Bolligenstrasse 111, 3000 Bern, Switzerland

Tel: +413193095 43; Fax: +41319309921

g.hasler@bluewin.ch

Total word count: 10,349; text body: 5,305

Number of tables: 2

Number of figures: 0

Number of supplementary material: 0 


\section{Abstract}

In bipolar disorders, there are unclear diagnostic boundaries with unipolar depression and schizophrenia, inconsistency of treatment guidelines, relatively long trial-and-error phases of treatment optimization, and increasing use of complex combination therapies lacking empirical evidence. These suggest that the current definition of bipolar disorders based on clinical symptoms reflects a clinically and etiologically heterogeneous entity. Stratification of treatments for bipolar disorders based on biomarkers and improved clinical markers are greatly needed to increase the efficacy of currently available treatments and improve the chances of developing novel therapeutic approaches. This review provides a theoretical framework to identify biomarkers and summarizes the most promising markers for stratification regarding beneficial and adverse treatment effects. State and stage specifiers, neuropsychological tests, neuroimaging, and genetic and epigenetic biomarkers will be discussed with respect to their ability to predict the response to specific pharmacological and psychosocial psychotherapies for bipolar disorders. To date, the most reliable markers are derived from psychopathology and history-taking, while no biomarker has been found that reliably predicts individual treatment responses. This review underlines both the importance of clinical diagnostic skills and the need for biological research to identify markers that will allow the targeting of treatment specifically to sub-populations of bipolar patients who are more likely to benefit from a specific treatment and less likely to develop adverse reactions.

Key words: bipolar disorder, stratified medicine, personalized medicine, precision medicine, treatment optimization 
Psychiatric research goes to great lengths to develop tests that can predict specific therapeutic successes (Frey et al., 2013). Such tests allow for adjustment of therapies to pathological processes and are of clinical relevance if the estimation of therapeutic success based on conventional diagnostic methods is imprecise. More specifically, stratified medicine intends to bring into line diagnosis, therapy, and prevention with the genetic predisposition of patients. In the case of bipolar disorders, no risk genes and no genes associated with treatment success have been reliably identified. In this review, the term "stratified medicine" has been broadened to include all kinds of predictors of therapy success. At the end of the article, we focus on the potential of genetic and epigenetic markers in bipolar disorders.

\section{Why stratifying treatments for bipolar disorders?}

There is much evidence that conventional diagnosis of bipolar disorders is imprecise (Angst, 2004, 2008; Angst et al., 2010; Simpson et al., 2002; Zimmermann et al., 2009). While international treatment guidelines of frequent psychiatric disorders, such as major depression or schizophrenia, are relatively consistent, the guidelines for bipolar disorders are strikingly inconsistent and heterogeneous (Nivoli et al., 2011) . This is particularly the case for bipolar depression in which considerable differences between recently published national and international treatment guidelines exist (Samalin et al., 2013). Despite the large number of clinical studies on bipolar depression, fundamental questions remain unclear. Thus, there is no consistent approach regarding whether bipolar depression should primarily be treated by a mono-therapy or combined therapy (Licht et al., 2008). Evidence-based expert opinions diverge considerably regarding the role of lithium and lamotrigine (Calabrese et al., 2008; Geddes et al., 2009). Additionally, the application of antidepressants is unclear (Pacchiarotti et al., 2013) . Even quetiapine, with relatively consistent evidence of efficacy, is not recommended as a first-line treatment in all guidelines. Further evidence for the urgent need of better diagnosis are the relatively low mean response rates of antidepressant 
(McElroy et al., 2010), anti-manic (Cipriani et al., 2011) and mood-stabilizing treatments in bipolar disorders; insufficient prediction of adverse drug reaction; long trial-and-error phases of treatment adjustment; and increasing use of complex combination therapies without solid evidence.

\section{Stratification based on psychopathological characteristics}

The American Psychiatric Association's third edition of the Diagnostic and Statistical Manual (DSM-III, 1980) aimed to operationalize clinical psychiatric diagnosis. This was required in order to study scientific diagnosis and markers regarding prediction of treatment success. A group of experts defined clusters of symptom patterns for courses as diagnostic criteria based on their clinical experience. In this way, defined diagnoses have been validated by epidemiological methods. Validation was mainly based on the criteria of Robins und Guze (Robins and Guze, 1970); the predictive efficiency and stability of diagnosis were evaluated by longitudinal studies and consistency of risk factors have been examined in family studies. As genetic risk factors in severe psychiatric diseases, such as schizophrenia and bipolar disorder, are of great importance, family studies became the most important method for validation of diagnostic criteria. The concept of bipolar disorder owes its success to family studies simultaneously conducted and published by Jules Angst und Carlo Perris (Angst and Perris, 1968). Those studies demonstrated an increased risk for bipolar disorder in relatives of bipolar patients, whereas the risk in relatives of patients suffering from major depression was not increased. 
From a present-day perspective, subdivision of affective disorders into unipolar and bipolar subtypes has been a great success of psychiatric epidemiology because these subtypes are not only distinct with regard to etiology and clinical course, but also in terms of responding to pharmacologic treatment. In particular, the specific relapse prevention with lithium impressionably demonstrates the benefit of this diagnostic concept (Geddes et al., 2004).

In recent years, clinical research has identified psychopathologic markers in patients with bipolar disorder that contribute to the prediction of treatment success. Those findings describe an important step towards stratified treatments. Thus, a typical manic-depressive course with full inter-episode remission predicts a good efficiency of lithium. Mixed manic-depressive forms respond relatively well to second-generation antipsychotics, such as olanzapine or asenapine (Grunze and Azorin, 2014; Kruger et al., 2005). Agitation in manic episodes is associated with good efficiency of loxapine, asenapine, and aripiprazole (Brown et al., 2013; Kwentus et al., 2012; McIntyre et al., 2009). Seasonal forms are positive predictors for a response to light therapy (Golden et al., 2005), while forms with predominant depressive episodes predict a good prophylactic effect of lamotrigine (Colom et al., 2006). Since lithium has a potent anti-suicidal effect and reduces suicide risk by $80 \%$ in individuals with affective disorders (Baldessarini et al., 2006), an increased suicidal risk is an important predictor for the use of lithium-treatment, irrespective of its mood-stabilizing effect. This stratified use of lithium corresponds relatively well with the goal of stratified medicine to adjust therapies to disease processes. This is because we assume that lithium reduces the specific lethality of suicidal attempts by inhibition of aggressive impulses.

Besides the aforementioned progresses in clinical practice, serious disadvantages and fundamental questions remained unanswered despite decades of intensive research. There are substantial problems with the concept of bipolar disorder: 1) Depressive disorders become apparent as bipolar disorders only over time as patients are not treated in an optimum manner for years; 2) Past manic episodes are poorly remembered, which leads to further misdiagnosis (Angst et al., 2005a); and 3) There is substantial uncertainty about where to draw the line between unipolar and bipolar affective 
disorders. Jules Angst and others have convincingly proven that-based on epidemiologic criteria, such as family history, course, and comorbidity-up to $40 \%$ of patients with major depressive disorders diagnosed based on the DSM-IV criteria suffer from subsyndromal hypomania and should therefore be classified as bipolar spectrum disorder(Angst et al., 2011; Angst et al., 2010). As listed in Table 1, various clinical characteristics have been identified to predict bipolar spectrum disorders (Angst et al., 2005b; Dudek et al., 2013; Lapalme et al., 1997).

However, there is evidence from placebo-controlled randomized clinical trials that subsyndromal manic states and maniform symptoms are less relevant for the choice of therapeutic approach than previously assumed. Thus, antidepressants in bipolar spectrum disorders might be as effective as they are in unipolar depression (Perlis et al., 2011), and with antidepressant-treated manic symptoms, they may not occur more often in spectrum disorders than without treatment. In contrast, other studies have reported the presence of subthreshold manic symptoms as a predictor of poor antidepressant response in bipolar depression (Pacchiarotti et al., 2011). This controversy indicates that stratification based on the criteria of Robins and Guze may not necessarily contribute to stratification of treatment strategies (Robins and Guze, 1970). Only markers with predictive value in terms of therapeutic response have the potential to improve the therapeutic practice in a crucial way (Perlis, 2011). To this end, treatment studies with patients with bipolar II disorder and bipolar spectrum disorders are of high clinical relevance. Overall limits are set to personalize treatment based on psychopathologic characteristics because many clinical symptoms are unspecific and allow no inferences about the underlying disease processes.

\section{Stratification based on endophenotypic markers}

The concept of endophenotypes

Gottesman and Shields (Gottesman and Shields, 1973) recognized early a fundamental problem of psychiatric genetics. Psychiatric conditions, as defined in the DSM and other established diagnostic 
manuals, do not represent adequate phenotypes for research since they are conceptualized as syndromes and are not related to mechanisms of illness. Furthermore, they assumed a long pathway from genes to clinical symptoms, which is difficult to reveal because of complex gene-by-gene interactions and gene-by-environment interactions over time. Despite intensive and expensive research, no risk genes for strong hereditable psychiatric diseases like bipolar disorders and schizophrenia have been reliably identified. This seems to acknowledge that they were right (Sullivan et al., 2012). In theoretical articles, they suggested vanquishing this methodical weakness of psychiatric genetics through the implementation of endophenotypes.

Endophenotypes are intermediate phenotypes standing between genes and gene products on the one hand and clinical syndromes on the other hand. The concept of endophenotypes assumes that there are fewer genes and less complex gene-environment interactions involved in the variation of endophenotypes than in psychological syndromes (Glahn et al., 2014; Gottesman and Gould, 2003).

Thus, it seems useful to identify genetic factors underlying endophenotypes in the first step and associate the biological consequences of the identified gene variants with clinical symptoms afterwards. Endophenotypes can be categorized according a gradient between genes and clinical symptoms: for example, neuropsychological endophenotypes are located nearer to the symptoms whereas concentrations of neurotransmitters measured by magnetic resonance spectroscopy (MRS) lie nearer to the genetic pole of the gradient. In other words, the endophenotype approach assumes that genetic underpinnings of molecular biological measures is less complex than those of complex behaviors irrespective of the heritability of the phenotype's total genetic risk. (Hasler et al., 2006). The validation criteria for endophenotypes involve the relationship with psychiatric disorders, heredity, independence from changing clinical symptomatology, and increased occurrence in healthy relatives (Hasler et al., 2006; Hasler et al., 2004). The later criterion ensures an association between the genetic risk factors of the endophenotype and those of illness (Hasler and Northoff, 2011). Endophenotypes are not diagnostic markers in a traditional sense (i.e., specificity and sensitivity of a 
specific psychiatric disorder are not validation criteria). In the context of stratified medicine (Schumann et al., 2014), it is to be expected that endophenotypes that are related to both risk genes and clinical symptoms can help to tailor psychiatric diagnostic, therapy, and prevention to pathological processes.

\section{Neuropsychology}

In schizophrenia, measures of general cognitive performance meet the validation criteria of endophenotypes (Snitz et al., 2006; Yeo et al., 2014). An advantage of such simple neuropsychological endophenotypes is that they can be effortlessly assessed in studies with large samples as well as in clinical daily routines.

Its disadvantage is that they exist near the symptom-pole on a symptom-genotype-gradient. In the case of bipolar disorder, there is an additional disadvantage that studies on neuropsychological deficits in bipolar patients and their healthy relatives revealed contradictory results (Bora et al., 2009). Common cognitive deficits appear to not be a risk factor of bipolar disorder. In fact, there is evidence that an above-average intelligence quotient during adolescence is a risk for the later occurrence of a bipolar disorder (MacCabe et al., 2010). Deficits in verbal learning and verbal memory meet the criteria of endophenotypes best (Balanza-Martinez et al., 2008; Hasler et al., 2006), followed by attention deficits and disturbance executive functions like response inhibition (Bora et al., 2009).

Loss of interests, reduced reaction upon positive events, and lack of motivation are core symptoms of bipolar depression, whereas uncontrollable excitation and increased motivation are core symptoms of mania. These symptoms point to dysregulation of the reward system, which is determinative of the regulation of motivation and drive. Relatively simple behavioral experiments, such as the monetary incentive delay task are proper for quantifying the disturbance of this system in affective disorders (Hasler et al., 2009; Knutson et al., 2008; Pizzagalli et al., 2009; Stoy et al., 2012). 
Since such measures are dependent on current affective symptoms, they might not qualify for endophenotypes. The validity of such measures in terms of the underlying pathological processes in affective disorders can be improved by combining them with pharmacological manipulation. As dopamine plays a central role in the brain reward system, substances enhancing or inhibiting dopamine neurotransmission are often used (Hasler et al., 2006; Hasler et al., 2009). This approach is comparable with the glucose intolerance test, which is more convincing in the diagnosis of diabetes mellitus than simple measures of the fasting plasma glucose concentration. Nevertheless, the utility of such combined measures in research and practice are considerably limited by their complexity and costs.

\section{Neuroeconomics}

A new, important contribution derives from behavioral economics. The economic decision theory assumes that options of action are represented in the brain(Glimcher and Rustichini, 2004). The brain reward system assigns a value to each of these options (Schultz, 2006). The option of action with the greatest value will be selected and executed. Finally, the reward system evaluates the outcome, which determines future representation and evaluation processes. Extensions of this theory regard the influence of uncertainty, and temporal and social factors on decision making. Neuroeconomic research has convincingly proven that decision theory qualifies for investigation the neurobiology of the human motivation (Rangel et al., 2008). Since motivation disorders are a central feature of affective disorders, neuroeconomics has the potential to revolutionize psychiatric research (Hasler, 2012). Chandler and co-workers showed by means of behavioral experiments based on the theory of expected utility that persons with bipolar disorder exhibit a complex dysregulation of risk-evaluation which facilitates the alternations of depressive and manic phases (Chandler et al., 2009). Future research will show if such experiments are suitable to uncover pathological processes in affective disorders, which would be an important step toward stratified treatment. 


\section{Functional imaging}

Current imaging methods allow the measuring of functional, structural, and chemical changes in patients with bipolar disorders. The considerable differences of these applied methods, commonly small samples, and rather low consistency of the findings complicate the possibility to describe precisely the pathological processes in bipolar or other disorders in terms of the dysfunctional brain region and neural networks.

The findings of functional imaging studies are particularly heterogeneous and therefore difficult to interpret with regard to applicability as endophenotypes (Keener and Phillips, 2007; Vargas et al., 2013). In addition, the use of psychological experiments, which differ from study to study, contribute to heterogeneity. A relatively well-examined paradigm in affective disorders is the measurement of neural reactions to emotional facial expressions. This paradigm has demonstrated a relatively consistent increased neural activity of subcortical, limbic brain regions (amygdala, parahippocampal formations, striatum) in combination with reduced activity of the lateral prefrontal cortex (Delvecchio et al., 2012). This pattern of findings is not specific for bipolar disorders but corresponds to the main finding of functional imaging studies of a broad spectrum of mood and anxiety disorders, including unipolar depression and anxiety disorder. Those findings will not be relevant for stratified medicine until it can be shown that they can be linked with therapy (e.g., if patients with strong increased subcortical activity respond better to a certain antidepressant treatment than persons without an increased activity). Antidepressants seem to be particularly efficacious in mood disorder patients with limbic hyperactivity (Chen et al., 2007; Mayberg et al., 1997). Additionally, deep brain stimulation seems to be particularly efficacious in patients with limbic hyperactivity that was normalized by stimulation (Mayberg et al., 2005). This is of special interest in the context of this review because Mayberg and colleagues recently found that deep brain stimulation is efficacious not 
only in unipolar but also in bipolar depression without provoking manic or hypomanic symptoms (Holtzheimer et al., 2012).

\section{Structural imaging}

Structural imaging studies in bipolar disorders yielded four main findings: 1) Abnormal brain volume of the anterior cingulate and a decreased integrity of white matter are associated with the genetic risk for bipolar disorders (McDonald et al., 2004; Whalley et al., 2013); 2) During the course of bipolar disorder, the regional brain volume decreases (Lim et al., 2013); and 3) Lithium-treated bipolar patients exhibit larger brain volumes on average than those who are not treated with lithium (Hallahan et al., 2011). 4) The frequency of white matter atrophic alterations are higher in bipolar disorder patients than in age-matched controls (typically bright spots in T2-weighted MRI images, also referred to as white matter hyperintensities) (Ahn et al., 2004; Aylward et al., 1994; Beyer et al., 2009; Marlinge et al., 2014).

There is some evidence that excessive release of corticosteroids, glutamate neurotoxicity, mitochondrial dysfunction, and stress-induced decrease of neurotrophic factors lead to the decrease of gray matter (Munakata et al., 2005; Nugent et al., 2006; Snyder et al., 2011; Stork and Renshaw, 2005). These neurotrophic and neurotoxic processes, which putatively contribute to an increased relapse risk in the course of illness, have important implications in terms of stratification of treatments. It seems natural that pathological processes differ not only between persons but also between stages of illness. A recent Task Force Report of the International Society for Bipolar Disorders concluded that staging models have the potential to improve treatment selection in bipolar disorders, and that the broadly defined categories of early and late stage are heuristically useful (Kapczinski et al., 2014). Given the finding that response to an antidepressant correlates positively with gray matter volume of the anterior cingulate, insula, and right temporoparietal cortex (Chen et al., 2007), it is conceivable that antidepressants are basically efficacious in early stages of bipolar 
disorder. Moreover, there is preliminary evidence of an increase in gray matter volume as a longitudinal effect of a lithium treatment (Moore et al., 2009). In the presence of structural brain alterations, neuroprotective drugs, such as lithium and valproic acid, might be the best treatment options since they may positively interact with neurotrophic processes potentially underlying the clinical symptoms (Chiu et al., 2013). This hypothesis can be tested by treatment studies using structural imaging at the onset and end of controlled treatments.

Abnormalities in the sense of white matter hyperintensities are often observed in older patients after cerebrovascular insults as well as in patients with migraine. In bipolar disorders, such alterations typically emerge at an early age before or shortly after the onset of the disorder (Hasler et al., 2006). This indicates that impairments of neuroplasticity and cellular resilience, which potentially lead to neural atrophy and cell death, are important pathological processes in bipolar disorder (Fries et al., 2014; Machado-Vieira et al., 2014). In accordance with this hypothesis is the observation that white matter hyperintensities predict a good response to treatment with lithium (Kato et al., 2000).

\section{Magnetic resonance spectroscopy}

MRS is a relatively new imaging method, which enables the measurement of the concentration of specific molecules. The most consistent MRS finding in bipolar disorder has been an increase in Glx in the prefrontal cortex (Gigante et al., 2012), namely in all examined prefrontal brain regions irrespective of medication. Glx reflects the total concentration of glutamate and glutamine. By interpreting this finding, one has to take into account that Glx is not a direct measurement of glutamatergic neurotransmission, because only $20 \%$ of glutamate in the brain serves as a neurotransmitter; $80 \%$ has a metabolic function. In this sense, bipolar disorder can be considered as a metabolic brain disorder. That blockade of mitochondrial metabolism leads to an increase of glutamate (Clausen et al., 2001) suggests that mitochondrial dysfunction plays a role in the pathogenesis of bipolar disorder (Stork and Renshaw, 2005). Mood stabilizing medications, such as 
lithium, valproic acid, and lamotrigine, modulate the glutamate system; it would be important to know, in the sense of stratified medicine, whether or not there is a correlation between abnormal prefrontal Glx and efficacy of these medications. There is preliminary evidence for an association between low pretreatment glutamine levels and a good antidepressant efficacy of ketamine (Salvadore et al., 2012). As decreased Glx is relatively consistent, as per MRS findings in unipolar depression, Glx has the additional potential to enable a biological valid differentiation between unipolar and bipolar affective disorders (Hasler and Northoff, 2011).

\section{Immunology}

Compared with the general population and with humans with unipolar depression, bipolar patients' risk of premature death is 1.5 to 3 -fold increased, irrespective of the risk of suicide. The main reason for this excess mortality is thought to be the high comorbidity with somatic diseases: up to $80 \%$ of bipolar patients also suffer from metabolic and/or cardiovascular disease (Swartz and Fagiolini, 2012; Taylor and MacQueen, 2006). This high rate of somatic comorbidity cannot be explained only by unwanted side effects of pharmacotherapy or by unhealthy lifestyle; rather, it points to common pathogenetic processes. Based on immunological studies, it has been proposed that bipolar disorder be understood as a multisystem inflammatory disease (Leboyer et al., 2012). This hypothesis is based on the frequent observation of increased pro-inflammatory proteins, such as interleukin- 6 and tumor necrosis factor alpha in both bipolar disorder and cardiovascular disease (Kunz et al., 2011). Interleukin- 6 has appeared to be associated with illness progression and late stages of the disease (Grande et al., 2014). Therapies that act upon these immunologic processes will contribute to more targeted treatment in inflammation-associated bipolar disorders. Such treatments likely contribute to the reduction of excess morbidity and mortality in patients with bipolar disorder. 


\section{Stratified psychotherapy of bipolar disorders}

Apart from psychoeducation, many forms of psychotherapy in bipolar disorders have proven effective. Interpersonal and social rhythm therapy, cognitive behavioral therapy, and family-focused therapy increase the probability of recovery, decrease time to recovery, and improve interpersonal skills and life satisfaction (Miklowitz, 2006). Similarly, pharmacotherapy response rates are typically low to moderate and scientific criteria on the selection of specific types of psychotherapy related to individual characteristics and the state of the illness are still lacking (Reinares et al., 2014). This lack can lead to long trial-and-error phases and may considerably reduce the effectiveness of psychological treatments. Psychotherapy research has labeled the lack of significant differences among effect sizes of available psychotherapies as the "Dodo bird verdict," referring to Carroll's novel "Alice's Adventures in Wonderland," in which Dodo said: "Everybody has won, and all must have prizes." However, this verdict is only correct at the group level and there is evidence that responses to distinct therapeutic methods and distinct therapists vary considerably across individual patients. Staging and illness awareness may be particularly relevant predictors of the response to psychosocial interventions. For example, patients with no insight and willingness to participate in such interventions may particularly benefit from family psychoeducation, rather than from patientfocused interventions. 
There are some promising leads that personality characteristics can predict responses to psychotherapy. For example, dependent personality traits may be a positive predictor of the response to highly structured behavioral therapy (Grawe, 2004). The state of an illness may be another important predictor of psychotherapy response. Data from controlled studies point to the finding that patients with only a few episodes benefit more from psychoeducation and psychotherapy than patients in late illness states (Reinares et al., 2014). In contrast, patients with chronic bipolar disorder may particularly benefit from psychological interventions that focus on specific functional impairments, such cognitive, interpersonal, and work-related deficits (Popovic et al., 2012; Torrent et al., 2013). Recent data suggest that functional remediation is not only effective in late stages of bipolar-I-disorder, but also of bipolar-II-disorder (Sole et al., 2014).

Many psychotherapies include a "personalization" of their interventions. For example, in behavioral activation, positive activities with antidepressant effects are systematically assessed, sometimes using extensive lists of potentially pleasurable activities. This kind of personalization of psychotherapies has great potential because it takes advantage of the fact that the response to behavioral change can usually be assessed easier and faster than the response to biological interventions. This potential should be used more systematically in the sense of stratified medicine. The interpersonal and social rhythm therapy has been invented with the intention of specifically acting upon a disturbance of the circadian rhythm (Frank et al., 2005; Frank et al., 2000). This disturbance is likely an important process of disease in bipolar patients. An indication for it is the occurrence of hypomanic symptoms after sleep deprivation (Hasler et al., 2006). The relatively wellestablished biology and genetics of circadian rhythm will possibly contribute to the development of biomarkers that predict the response to treatments modifying the circadian rhythm.

\section{Adverse drug reactions}


Frequent problems with compliance and common somatic comorbidities in bipolar disorders means that drugs are not only chosen based on their effect but also based on their profile of adverse drug reactions (ADR). Stratification based on ADR profiles is relatively well advanced. The corrected QT interval derived from modern electrocardiogram machines is increasingly used to assess the threat of severe cardiac ADRs. This is particularly of great importance when drugs are combined since a drugprolonging QTc can potentiate in drug combination. Risk factors of the metabolic syndrome-

such as abdominal fat distribution and increased serum triglyceride, HDL cholesterol, blood pressure, and fasting glucose-represent relative contraindications for atypical antipsychotics, which cause frequent metabolic ADRs. Polysomnography can help to assess the danger of respiratory depressive psychotropic drugs. The identification of subjects carrying the HLA-B*1502 allele and the avoidance of carbamazepine therapy in these subjects has been strongly associated with a decrease in the incidence of carbamazepine-induced Stevens-Johnson syndrome and toxic epidermal necrolysis (Chen et al., 2011). The success of this "stratification" is considerable; despite increasing polypharmacy, the frequency of dangerous ADRs is decreasing (Greil et al., 2012).

\section{Genetics}

Genetic factors constitute approximately $90 \%$ of bipolar I disorder causes (Kieseppa et al., 2004; McGuffin et al., 2003). However, identification of individual risk genes is still unsuccessful. This is striking since risk genes have been found for complex genetic diseases with lower heritability than bipolar disorder, such as diabetes mellitus, Alzheimer's disease, and breast cancer (Hasler et al., 2006).

As mentioned above, a major problem of psychiatric genetics is the fact that psychiatric disorders are defined as syndromal rather than based on pathologic processes. In this case, diverse pathological processes leading to the clinical image of bipolar disorder identification of risk genes of bipolar disorder as a symptom-based, defined phenotype is complicated or impossible (Kendler, 2006). 
Another problem is the assessment of genetic variance. Even genome-wide association studies assess only a section of a possible variance; namely, the commonly occurring single nucleotide polymorphisms (SNPs). If, for example, very rare or spontaneous polymorphisms play an important role in the pathogenesis of bipolar disorders, they would not be detected by current methods (Kerner, 2014).

Recent new mathematical methods enable the computation of the amount of risk of illness contingent on SNPs, which are usually determined by GWAS studies (Kendler, 2013). A corresponding study showed that a $41 \%$ risk for bipolar I disorder is defined by the GWAS data of Wellcome Trust Case Control Consortium (Lee et al., 2011). This is considerably more than in schizophrenia (14-24\%) or somatic diseases, such as Crohn's disease (24\%) and diabetes mellitus type 1 (31\%). This suggests that there is no fundamental hurdle regarding the way to the itemization of the genetics of bipolar disorders. Presumably, many genetic factors contribute to the risk of disease, each with a small effect. Such effects can be proven only in very large samples.

In bipolar disorders, the risk gene candidates with the best evidence are CACNA1C and ANK3 (Craddock and Sklar, 2013; Muhleisen et al., 2014). Both genes code for proteins regulate, as part of the ion channels, the neuronal excitability. These findings suggest that ion channels are decisive in the pathogenesis of bipolar disorders and drugs that act on ion channels may have therapeutic effects.

Regarding stratification of currently available therapies, genetic markers are crucial to predict treatment success. Thus far, identification of such markers has not been successful (Chen et al., 2014; Hou et al., 2014). GWAS studies exist at present exclusively for the effectiveness of lithium, which is in large part heritable according to family studies (Ewald et al., 1999; Turecki et al., 2001). These studies did not provide conclusive results, although they provided evidence that GRIA2, a protein of the AMPA glutamate receptor, plays a role in the lithium effect (Perlis et al., 2009). Genes related to 
impulsivity and suicide risk such as IMPA1 and 2, INPP1, GSK3 $\alpha$ and $\beta$ (Jimenez et al., 2013) may also be candidate genetic markers for the response to lithium.

Candidate gene studies also showed that the gene $X B P 1$, which affects cellular reactions to stress, may be a potential predictor of the therapeutic effect of valproic acid (Kim et al., 2009). Candidate genes for the prediction of the effect of lithium in bipolar patients, including the BDNF Met allele of rs6265 coding for an important neurotrophic factor, plays an important role in brain aging processes and chronification of psychiatric disorders (Salehi et al., 2013; Wang et al., 2012). Studies on the effect of monoaminergic antidepressants show that polymorphisms of the serotonin transporter gene and the gene for serotonin receptor $5 \mathrm{HT} 1 \mathrm{~A}$ have the potential to assess the antidepressant effect (Serretti et al., 2004; Severino et al., 2013; Zanardi et al., 2001).

\section{Epigenetics}

Each cell of our body contains an epigenetic imprint of experience in its genome. Some epigenetic changes can be inherited through multiple generations. The epigenetic patterning occurs at the level of whole chromosomes and of large chromosomal regions down to the single nucleotide level. A relatively well-examined epigenetic change involves the acetylation of histones leading to the local loosening of DNA and increased gene reading in this section. In contrast, histone methylation inhibits gene expression in specific gene sections. At the level of the DNA, methylation and demethylation of DNA inhibit and, respectively, enhance the expression of specific genes (Pena et al., 2014).

There is preliminary evidence for epigenetic changes playing a role in the pathogenesis of bipolar disorders (Xiao et al., 2014). Preliminary findings suggest that the cerebral epigenetic inhibition of the GABAergic gene expression contribute to the development of bipolar disorders (Guidotti et al., 2011). A typical trait of this pathology is a low expression of glutamic acid decarboxylase 67 (GAD67), which synthesize GABA. This results in attenuation of the inhibiting GABA system. 
Pathogenic DNA sequences are very stable whereas epigenetic changes are reversible and therefore qualify for pharmacological targets. Valproic acid is a potent inhibitor of various histone deacetylases (HDACs). It has been showed that valproic acid specifically encourages the promoter demethylation of the GAD67 gene and, therefore, GAD67 expression (Dong et al., 2010). Other drugs promoting DNA methylation applied in bipolar disorders are clozapine and sulpiride (Dong et al., 2008).

All of these findings suggest that epigenetic changes have a great potential to improve the stratification of psychiatric treatment as biomarkers. Yet the main problem is that the majority of epigenetic changes are specific for cells and tissues. To what extent epigenetic changes measured in blood cells provide information about the epigenome of the brain is currently unclear.

\section{Conclusion}

The current process of diagnosing bipolar disorders based solely on clinical symptoms has crucial weaknesses. Evidence for these weaknesses are low average response rates, long phases of treatment adjustment, and inconsistent treatment guidelines.

Employing methods of neuropsychology, neuroradiology, immunology, genetics, and epigenetics, biomarkers have been proposed and evaluated. Table 2 summarizes the most promising clinical and biological markers to predict responses to specific treatments. To date, the most reliable markers are derived from psychopathology and history taking. Although there are a number of promising leads, no neuropsychological or biological markers have been found thus far that reliably predict individual therapy effectiveness.

NIMH's Research Domain Criteria (RDoC) (Morris and Cuthbert, 2012) provides a promising new research framework that takes a dimensional approach to the study of the genetic, neural and behavioral features of mental disorders. The domains "negative valence system" related to stress sensitivity and anxiety, "positive valence system" related to reward processing, and "systems for 
social processes" may be particularly important for the study of bipolar disorders. The main limitation of such a neuroscience-based approach to psychiatric diagnostics has been the missing link between clinical states and biomarkers (Fava et al., 2014). A transition from DSM to RDoC will have to incorporate various combinations DSM disorder categories and dimensional RDOC constructs in experiments (Cuthbert, 2014). However, the high clinical utility of DSM concepts will likely be a major obstacle in this transition. In addition, the RDoC approach emphasizes cross-sectional assessment, while abnormal neurodevelopment is an important aspect in the pathogenesis of bipolar disorder. Identifying sensitive periods for the RDoC constructs will improve understanding of environmental pathogenetic components and enhance the precision of stage-related therapeutic interventions (Casey et al., 2014). Changing the paradigm for drug development for bipolar disorders based on the RDoC proposal may counteract the declining assay sensitivity of clinical trials and contribute to moving clinical research toward hard outcomes, such as biomarkers, and ecological measures of functional benefits (Vieta, 2014).

For clinicians, it is important to completely exploit clinical markers predicting therapy effects in bipolar disorders, including degree of severity, type I/II classification, typical course of illness, family anamnesis, mixed states of manic and depressive phases, predominant polarity, degree of agitation, and suicidal risk (Fava et al., 2014).

The best current predictors for treatment success are previous responses to a certain treatment and the evidence of an effective treatment in relatives with bipolar disorder. 


\section{References}

Ahn, K.H., Lyoo, I.K., Lee, H.K., Song, I.C., Oh, J.S., Hwang, J., Kwon, J., Kim, M.J., Kim, M., Renshaw, P.F., 2004. White matter hyperintensities in subjects with bipolar disorder. Psychiatry Clin Neurosci 58, 516-521.

Angst, J., 2004. Bipolar disorder--a seriously underestimated health burden. Eur Arch Psychiatry Clin Neurosci 254, 59-60.

Angst, J., 2008. Bipolar disorder--methodological problems and future perspectives. Dialogues Clin Neurosci 10, 129-139.

Angst, J., Adolfsson, R., Benazzi, F., Gamma, A., Hantouche, E., Meyer, T.D., Skeppar, P., Vieta, E., Scott, J., 2005a. The HCL-32: towards a self-assessment tool for hypomanic symptoms in outpatients. J Affect Disord 88, 217-233.

Angst, J., Azorin, J.M., Bowden, C.L., Perugi, G., Vieta, E., Gamma, A., Young, A.H., 2011. Prevalence and characteristics of undiagnosed bipolar disorders in patients with a major depressive episode: the BRIDGE study. Arch Gen Psychiatry 68, 791-798.

Angst, J., Cui, L., Swendsen, J., Rothen, S., Cravchik, A., Kessler, R.C., Merikangas, K.R., 2010. Major depressive disorder with subthreshold bipolarity in the National Comorbidity Survey Replication. Am J Psychiatry 167, 1194-1201.

Angst, J., Perris, C., 1968. Zur Nosologie endogener Psychosen. Vergleich der Ergebnisse zweier Untersuchungen. Arch Psychiatr Nervenkr 210, 373-386.

Angst, J., Sellaro, R., Stassen, H.H., Gamma, A., 2005b. Diagnostic conversion from depression to bipolar disorders: results of a long-term prospective study of hospital admissions. J Affect Disord 84, 149-157.

Aylward, E.H., Roberts-Twillie, J.V., Barta, P.E., Kumar, A.J., Harris, G.J., Geer, M., Peyser, C.E., Pearlson, G.D., 1994. Basal ganglia volumes and white matter hyperintensities in patients with bipolar disorder. Am J Psychiatry 151, 687-693.

Balanza-Martinez, V., Rubio, C., Selva-Vera, G., Martinez-Aran, A., Sanchez-Moreno, J., Salazar-Fraile, J., Vieta, E., Tabares-Seisdedos, R., 2008. Neurocognitive endophenotypes (endophenocognitypes) from studies of relatives of bipolar disorder subjects: a systematic review. Neurosci Biobehav Rev 32, 1426-1438.

Baldessarini, R.J., Tondo, L., Davis, P., Pompili, M., Goodwin, F.K., Hennen, J., 2006. Decreased risk of suicides and attempts during long-term lithium treatment: a meta-analytic review. Bipolar Disord 8, 625-639.

Beyer, J.L., Young, R., Kuchibhatla, M., Krishnan, K.R., 2009. Hyperintense MRI lesions in bipolar disorder: A meta-analysis and review. Int Rev Psychiatry 21, 394-409.

Bora, E., Yucel, M., Pantelis, C., 2009. Cognitive endophenotypes of bipolar disorder: a meta-analysis of neuropsychological deficits in euthymic patients and their first-degree relatives. J Affect Disord 113, 1-20.

Brown, R., Taylor, M.J., Geddes, J., 2013. Aripiprazole alone or in combination for acute mania. Cochrane Database Syst Rev 12, CD005000.

Calabrese, J.R., Huffman, R.F., White, R.L., Edwards, S., Thompson, T.R., Ascher, J.A., Monaghan, E.T., Leadbetter, R.A., 2008. Lamotrigine in the acute treatment of bipolar depression: results of five double-blind, placebo-controlled clinical trials. Bipolar Disord 10, 323-333.

Casey, B.J., Oliveri, M.E., Insel, T., 2014. A neurodevelopmental perspective on the research domain criteria (RDoC) framework. Biol Psychiatry 76, 350-353.

Chandler, R.A., Wakeley, J., Goodwin, G.M., Rogers, R.D., 2009. Altered risk-aversion and risk-seeking behavior in bipolar disorder. Biol Psychiatry 66, 840-846.

Chen, C.H., Lee, C.S., Lee, M.T., Ouyang, W.C., Chen, C.C., Chong, M.Y., Wu, J.Y., Tan, H.K., Lee, Y.C., Chuo, L.J., Chiu, N.Y., Tsang, H.Y., Chang, T.J., Lung, F.W., Chiu, C.H., Chang, C.H., Chen, Y.S., Hou, Y.M., Lai, T.J., Tung, C.L., Chen, C.Y., Lane, H.Y., Su, T.P., Feng, J., Lin, J.J., Chang, C.J., Teng, P.R., Liu, C.Y., Chen, C.K., Liu, I.C., Chen, J.J., Lu, T., Fan, C.C., Wu, C.K., Li, C.F., Wang, K.H., Wu, L.S., Peng, H.L., 
Chang, C.P., Lu, L.S., Chen, Y.T., Cheng, A.T., 2014. Variant GADL1 and response to lithium therapy in bipolar I disorder. N Engl J Med 370, 119-128.

Chen, C.H., Ridler, K., Suckling, J., Williams, S., Fu, C.H., Merlo-Pich, E., Bullmore, E., 2007. Brain imaging correlates of depressive symptom severity and predictors of symptom improvement after antidepressant treatment. Biol Psychiatry 62, 407-414.

Chen, P., Lin, J.J., Lu, C.S., Ong, C.T., Hsieh, P.F., Yang, C.C., Tai, C.T., Wu, S.L., Lu, C.H., Hsu, Y.C., Yu, H.Y., Ro, L.S., Lu, C.T., Chu, C.C., Tsai, J.J., Su, Y.H., Lan, S.H., Sung, S.F., Lin, S.Y., Chuang, H.P., Huang, L.C., Chen, Y.J., Tsai, P.J., Liao, H.T., Lin, Y.H., Chen, C.H., Chung, W.H., Hung, S.I., Wu, J.Y., Chang, C.F., Chen, L., Chen, Y.T., Shen, C.Y., 2011. Carbamazepine-induced toxic effects and HLA-B*1502 screening in Taiwan. N Engl J Med 364, 1126-1133.

Chiu, C.T., Wang, Z., Hunsberger, J.G., Chuang, D.M., 2013. Therapeutic potential of mood stabilizers lithium and valproic acid: beyond bipolar disorder. Pharmacol Rev 65, 105-142.

Cipriani, A., Barbui, C., Salanti, G., Rendell, J., Brown, R., Stockton, S., Purgato, M., Spineli, L.M., Goodwin, G.M., Geddes, J.R., 2011. Comparative efficacy and acceptability of antimanic drugs in acute mania: a multiple-treatments meta-analysis. Lancet 378, 1306-1315.

Clausen, T., Zauner, A., Levasseur, J.E., Rice, A.C., Bullock, R., 2001. Induced mitochondrial failure in the feline brain: implications for understanding acute post-traumatic metabolic events. Brain Res 908, 35-48.

Colom, F., Vieta, E., Daban, C., Pacchiarotti, I., Sanchez-Moreno, J., 2006. Clinical and therapeutic implications of predominant polarity in bipolar disorder. J Affect Disord 93, 13-17. Craddock, N., Sklar, P., 2013. Genetics of bipolar disorder. Lancet 381, 1654-1662.

Cuthbert, B.N., 2014. The RDoC framework: facilitating transition from ICD/DSM to dimensional approaches that integrate neuroscience and psychopathology. World Psychiatry 13, 28-35.

Delvecchio, G., Fossati, P., Boyer, P., Brambilla, P., Falkai, P., Gruber, O., Hietala, J., Lawrie, S.M., Martinot, J.L., McIntosh, A.M., Meisenzahl, E., Frangou, S., 2012. Common and distinct neural correlates of emotional processing in Bipolar Disorder and Major Depressive Disorder: a voxel-based meta-analysis of functional magnetic resonance imaging studies. Eur Neuropsychopharmacol 22, 100-113.

Dong, E., Chen, Y., Gavin, D.P., Grayson, D.R., Guidotti, A., 2010. Valproate induces DNA demethylation in nuclear extracts from adult mouse brain. Epigenetics 5, 730-735.

Dong, E., Nelson, M., Grayson, D.R., Costa, E., Guidotti, A., 2008. Clozapine and sulpiride but not haloperidol or olanzapine activate brain DNA demethylation. Proc Natl Acad Sci U S A 105, 1361413619.

Dudek, D., Siwek, M., Zielinska, D., Jaeschke, R., Rybakowski, J., 2013. Diagnostic conversions from major depressive disorder into bipolar disorder in an outpatient setting: results of a retrospective chart review. J Affect Disord 144, 112-115.

Ewald, H., Wang, A.G., Vang, M., Mors, O., Nyegaard, M., Kruse, T.A., 1999. A haplotype-based study of lithium responding patients with bipolar affective disorder on the Faroe Islands. Psychiatr Genet 9 , 23-34.

Fava, G.A., Guidi, J., Grandi, S., Hasler, G., 2014. The Missing Link between Clinical States and Biomarkers in Mental Disorders. Psychother Psychosom 83, 136-141.

Frank, E., Kupfer, D.J., Thase, M.E., Mallinger, A.G., Swartz, H.A., Fagiolini, A.M., Grochocinski, V., Houck, P., Scott, J., Thompson, W., Monk, T., 2005. Two-year outcomes for interpersonal and social rhythm therapy in individuals with bipolar I disorder. Arch Gen Psychiatry 62, 996-1004.

Frank, E., Swartz, H.A., Kupfer, D.J., 2000. Interpersonal and social rhythm therapy: managing the chaos of bipolar disorder. Biol Psychiatry 48, 593-604.

Frey, B.N., Andreazza, A.C., Houenou, J., Jamain, S., Goldstein, B.I., Frye, M.A., Leboyer, M., Berk, M., Malhi, G.S., Lopez-Jaramillo, C., Taylor, V.H., Dodd, S., Frangou, S., Hall, G.B., Fernandes, B.S., KauerSant'Anna, M., Yatham, L.N., Kapczinski, F., Young, L.T., 2013. Biomarkers in bipolar disorder: a positional paper from the International Society for Bipolar Disorders Biomarkers Task Force. Aust N Z J Psychiatry 47, 321-332. 
Fries, G.R., Vasconcelos-Moreno, M.P., Gubert, C., Santos, B.T., da Rosa, A.L., Eisele, B., Sartori, J., Pfaffenseller, B., Kapczinski, F., Kauer-Sant'anna, M., 2014. Early apoptosis in peripheral blood mononuclear cells from patients with bipolar disorder. J Affect Disord 152-154, 474-477.

Geddes, J.R., Burgess, S., Hawton, K., Jamison, K., Goodwin, G.M., 2004. Long-term lithium therapy for bipolar disorder: systematic review and meta-analysis of randomized controlled trials. Am J Psychiatry 161, 217-222.

Geddes, J.R., Calabrese, J.R., Goodwin, G.M., 2009. Lamotrigine for treatment of bipolar depression: independent meta-analysis and meta-regression of individual patient data from five randomised trials. Br J Psychiatry 194, 4-9.

Geddes, J.R., Miklowitz, D.J., 2013. Treatment of bipolar disorder. Lancet 381, 1672-1682.

Gigante, A.D., Bond, D.J., Lafer, B., Lam, R.W., Young, L.T., Yatham, L.N., 2012. Brain glutamate levels measured by magnetic resonance spectroscopy in patients with bipolar disorder: a meta-analysis. Bipolar Disord 14, 478-487.

Glahn, D.C., Knowles, E.E., McKay, D.R., Sprooten, E., Raventos, H., Blangero, J., Gottesman, II, Almasy, L., 2014. Arguments for the sake of endophenotypes: examining common misconceptions about the use of endophenotypes in psychiatric genetics. Am J Med Genet B Neuropsychiatr Genet 165B, 122-130.

Glimcher, P.W., Rustichini, A., 2004. Neuroeconomics: the consilience of brain and decision. Science 306, 447-452.

Golden, R.N., Gaynes, B.N., Ekstrom, R.D., Hamer, R.M., Jacobsen, F.M., Suppes, T., Wisner, K.L., Nemeroff, C.B., 2005. The efficacy of light therapy in the treatment of mood disorders: a review and meta-analysis of the evidence. Am J Psychiatry 162, 656-662.

Gonzalez, D., Bienroth, M., Curtis, V., Debenham, M., Jones, S., Pitsi, D., George, M., 2013. Consensus statement on the use of intramuscular aripiprazole for the rapid control of agitation in bipolar mania and schizophrenia. Curr Med Res Opin 29, 241-250.

Gottesman, II, Gould, T.D., 2003. The endophenotype concept in psychiatry: etymology and strategic intentions. Am J Psychiatry 160, 636-645.

Gottesman, II, Shields, J., 1973. Genetic theorizing and schizophrenia. Br J Psychiatry 122, 15-30.

Grande, I., Magalhaes, P.V., Chendo, I., Stertz, L., Panizutti, B., Colpo, G.D., Rosa, A.R., Gama, C.S., Kapczinski, F., Vieta, E., 2014. Staging bipolar disorder: clinical, biochemical, and functional correlates. Acta Psychiatr Scand 129, 437-444.

Grawe, K., 2004. Psychological Therapy, Revised Edition ed. Hogrefe Publishing.

Greil, W., Haberle, A., Haueis, P., Grohmann, R., Russmann, S., 2012. Pharmacotherapeutic trends in 2231 psychiatric inpatients with bipolar depression from the International AMSP Project between 1994 and 2009. J Affect Disord 136, 534-542.

Grunze, H., Azorin, J.M., 2014. Clinical decision making in the treatment of mixed states. World J Biol Psychiatry, 1-14.

Guidotti, A., Auta, J., Chen, Y., Davis, J.M., Dong, E., Gavin, D.P., Grayson, D.R., Matrisciano, F., Pinna, G., Satta, R., Sharma, R.P., Tremolizzo, L., Tueting, P., 2011. Epigenetic GABAergic targets in schizophrenia and bipolar disorder. Neuropharmacology 60, 1007-1016.

Hallahan, B., Newell, J., Soares, J.C., Brambilla, P., Strakowski, S.M., Fleck, D.E., Kieseppa, T., Altshuler, L.L., Fornito, A., Malhi, G.S., McIntosh, A.M., Yurgelun-Todd, D.A., Labar, K.S., Sharma, V., MacQueen, G.M., Murray, R.M., McDonald, C., 2011. Structural magnetic resonance imaging in bipolar disorder: an international collaborative mega-analysis of individual adult patient data. Biol Psychiatry 69, 326-335.

Hasler, G., 2012. Can the neuroeconomics revolution revolutionize psychiatry? Neurosci Biobehav Rev 36, 64-78.

Hasler, G., Drevets, W.C., Gould, T.D., Gottesman, II, Manji, H.K., 2006. Toward Constructing an Endophenotype Strategy for Bipolar Disorders. Biol Psychiatry 60, 93-105.

Hasler, G., Drevets, W.C., Manji, H.K., Charney, D.S., 2004. Discovering endophenotypes for major depression. Neuropsychopharmacology 29, 1765-1781. 
Hasler, G., Luckenbaugh, D.A., Snow, J., Meyers, N., Waldeck, T., Geraci, M., Roiser, J., Knutson, B., Charney, D.S., Drevets, W.C., 2009. Reward processing after catecholamine depletion in unmedicated, remitted subjects with major depressive disorder. Biol Psychiatry 66, 201-205. Hasler, G., Northoff, G., 2011. Discovering imaging endophenotypes for major depression. Mol Psychiatry 16, 604-619.

Holtzheimer, P.E., Kelley, M.E., Gross, R.E., Filkowski, M.M., Garlow, S.J., Barrocas, A., Wint, D., Craighead, M.C., Kozarsky, J., Chismar, R., Moreines, J.L., Mewes, K., Posse, P.R., Gutman, D.A., Mayberg, H.S., 2012. Subcallosal cingulate deep brain stimulation for treatment-resistant unipolar and bipolar depression. Arch Gen Psychiatry 69, 150-158.

Hou, L., Heilbronner, U., Rietschel, M., Kato, T., Kuo, P.H., McMahon, F.J., Schulze, T.G., 2014. Variant GADL1 and response to lithium in bipolar I disorder. N Engl J Med 370, 1857-1859.

Jimenez, E., Arias, B., Mitjans, M., Goikolea, J.M., Roda, E., Saiz, P.A., Garcia-Portilla, M.P., Buron, P., Bobes, J., Oquendo, M.A., Vieta, E., Benabarre, A., 2013. Genetic variability at IMPA2, INPP1 and GSK3beta increases the risk of suicidal behavior in bipolar patients. Eur Neuropsychopharmacol 23, 1452-1462.

Kapczinski, F., Magalhaes, P.V., Balanza-Martinez, V., Dias, V.V., Frangou, S., Gama, C.S., GonzalezPinto, A., Grande, I., Ha, K., Kauer-Sant'Anna, M., Kunz, M., Kupka, R., Leboyer, M., Lopez-Jaramillo, C., Post, R.M., Rybakowski, J.K., Scott, J., Strejilevitch, S., Tohen, M., Vazquez, G., Yatham, L., Vieta, E., Berk, M., 2014. Staging systems in bipolar disorder: an International Society for Bipolar Disorders Task Force Report. Acta Psychiatr Scand.

Kato, T., Fujii, K., Kamiya, A., Kato, N., 2000. White matter hyperintensity detected by magnetic resonance imaging and lithium response in bipolar disorder: a preliminary observation. Psychiatry Clin Neurosci 54, 117-120.

Keener, M.T., Phillips, M.L., 2007. Neuroimaging in bipolar disorder: a critical review of current findings. Curr Psychiatry Rep 9, 512-520.

Kendler, K.S., 2006. Reflections on the relationship between psychiatric genetics and psychiatric nosology. Am J Psychiatry 163, 1138-1146.

Kendler, K.S., 2013. What psychiatric genetics has taught us about the nature of psychiatric illness and what is left to learn. Mol Psychiatry 18, 1058-1066.

Kerner, B., 2014. Genetics of bipolar disorder. Appl Clin Genet 7, 33-42.

Kieseppa, T., Partonen, T., Haukka, J., Kaprio, J., Lonnqvist, J., 2004. High concordance of bipolar I disorder in a nationwide sample of twins. Am J Psychiatry 161, 1814-1821.

Kim, B., Kim, C.Y., Lee, M.J., Joo, Y.H., 2009. Preliminary evidence on the association between XBP1$116 \mathrm{C} / \mathrm{G}$ polymorphism and response to prophylactic treatment with valproate in bipolar disorders. Psychiatry Res 168, 209-212.

Knutson, B., Bhanji, J.P., Cooney, R.E., Atlas, L.Y., Gotlib, I.H., 2008. Neural responses to monetary incentives in major depression. Biol Psychiatry 63, 686-692.

Kohler, S., Gaus, S., Bschor, T., 2014. The challenge of treatment in bipolar depression: evidence from clinical guidelines, treatment recommendations and complex treatment situations.

Pharmacopsychiatry 47, 53-59.

Kruger, S., Trevor Young, L., Braunig, P., 2005. Pharmacotherapy of bipolar mixed states. Bipolar Disord 7, 205-215.

Kunz, M., Cereser, K.M., Goi, P.D., Fries, G.R., Teixeira, A.L., Fernandes, B.S., Belmonte-de-Abreu, P.S., Kauer-Sant'Anna, M., Kapczinski, F., Gama, C.S., 2011. Serum levels of IL-6, IL-10 and TNF-alpha in patients with bipolar disorder and schizophrenia: differences in pro- and anti-inflammatory balance. Rev Bras Psiquiatr 33, 268-274.

Kwentus, J., Riesenberg, R.A., Marandi, M., Manning, R.A., Allen, M.H., Fishman, R.S., Spyker, D.A., Kehne, J.H., Cassella, J.V., 2012. Rapid acute treatment of agitation in patients with bipolar I disorder: a multicenter, randomized, placebo-controlled clinical trial with inhaled loxapine. Bipolar Disord 14, 31-40.

Lapalme, M., Hodgins, S., LaRoche, C., 1997. Children of parents with bipolar disorder: a metaanalysis of risk for mental disorders. Can J Psychiatry 42, 623-631. 
Leboyer, M., Soreca, I., Scott, J., Frye, M., Henry, C., Tamouza, R., Kupfer, D.J., 2012. Can bipolar disorder be viewed as a multi-system inflammatory disease? J Affect Disord 141, 1-10.

Lee, S.H., Wray, N.R., Goddard, M.E., Visscher, P.M., 2011. Estimating missing heritability for disease from genome-wide association studies. Am J Hum Genet 88, 294-305.

Licht, R.W., Gijsman, H., Nolen, W.A., Angst, J., 2008. Are antidepressants safe in the treatment of bipolar depression? A critical evaluation of their potential risk to induce switch into mania or cycle acceleration. Acta Psychiatr Scand 118, 337-346.

Lim, C.S., Baldessarini, R.J., Vieta, E., Yucel, M., Bora, E., Sim, K., 2013. Longitudinal neuroimaging and neuropsychological changes in bipolar disorder patients: review of the evidence. Neurosci Biobehav Rev 37, 418-435.

MacCabe, J.H., Lambe, M.P., Cnattingius, S., Sham, P.C., David, A.S., Reichenberg, A., Murray, R.M., Hultman, C.M., 2010. Excellent school performance at age 16 and risk of adult bipolar disorder: national cohort study. Br J Psychiatry 196, 109-115.

Machado-Vieira, R., Soeiro-De-Souza, M.G., Richards, E.M., Teixeira, A.L., Zarate, C.A., Jr., 2014. Multiple levels of impaired neural plasticity and cellular resilience in bipolar disorder: developing treatments using an integrated translational approach. World J Biol Psychiatry 15, 84-95.

Marlinge, E., Bellivier, F., Houenou, J., 2014. White matter alterations in bipolar disorder: potential for drug discovery and development. Bipolar Disord 16, 97-112.

Mayberg, H.S., Brannan, S.K., Mahurin, R.K., Jerabek, P.A., Brickman, J.S., Tekell, J.L., Silva, J.A., McGinnis, S., Glass, T.G., Martin, C.C., Fox, P.T., 1997. Cingulate function in depression: a potential predictor of treatment response. Neuroreport 8, 1057-1061.

Mayberg, H.S., Lozano, A.M., Voon, V., McNeely, H.E., Seminowicz, D., Hamani, C., Schwalb, J.M., Kennedy, S.H., 2005. Deep brain stimulation for treatment-resistant depression. Neuron 45, 651-660. McDonald, C., Bullmore, E.T., Sham, P.C., Chitnis, X., Wickham, H., Bramon, E., Murray, R.M., 2004. Association of genetic risks for schizophrenia and bipolar disorder with specific and generic brain structural endophenotypes. Arch Gen Psychiatry 61, 974-984.

McElroy, S.L., Weisler, R.H., Chang, W., Olausson, B., Paulsson, B., Brecher, M., Agambaram, V., Merideth, C., Nordenhem, A., Young, A.H., 2010. A double-blind, placebo-controlled study of quetiapine and paroxetine as monotherapy in adults with bipolar depression (EMBOLDEN II). J Clin Psychiatry 71, 163-174.

McGuffin, P., Rijsdijk, F., Andrew, M., Sham, P., Katz, R., Cardno, A., 2003. The heritability of bipolar affective disorder and the genetic relationship to unipolar depression. Arch Gen Psychiatry 60, 497502.

McIntyre, R.S., Cohen, M., Zhao, J., Alphs, L., Macek, T.A., Panagides, J., 2009. A 3-week, randomized, placebo-controlled trial of asenapine in the treatment of acute mania in bipolar mania and mixed states. Bipolar Disord 11, 673-686.

Miklowitz, D.J., 2006. A review of evidence-based psychosocial interventions for bipolar disorder. J Clin Psychiatry 67 Suppl 11, 28-33.

Moore, G.J., Cortese, B.M., Glitz, D.A., Zajac-Benitez, C., Quiroz, J.A., Uhde, T.W., Drevets, W.C., Manji, H.K., 2009. A longitudinal study of the effects of lithium treatment on prefrontal and subgenual prefrontal gray matter volume in treatment-responsive bipolar disorder patients. J Clin Psychiatry 70, 699-705.

Morris, S.E., Cuthbert, B.N., 2012. Research Domain Criteria: cognitive systems, neural circuits, and dimensions of behavior. Dialogues Clin Neurosci 14, 29-37.

Muhleisen, T.W., Leber, M., Schulze, T.G., Strohmaier, J., Degenhardt, F., Treutlein, J., Mattheisen, M., Forstner, A.J., Schumacher, J., Breuer, R., Meier, S., Herms, S., Hoffmann, P., Lacour, A., Witt, S.H., Reif, A., Muller-Myhsok, B., Lucae, S., Maier, W., Schwarz, M., Vedder, H., Kammerer-Ciernioch, J., Pfennig, A., Bauer, M., Hautzinger, M., Moebus, S., Priebe, L., Czerski, P.M., Hauser, J., Lissowska, J., Szeszenia-Dabrowska, N., Brennan, P., McKay, J.D., Wright, A., Mitchell, P.B., Fullerton, J.M., Schofield, P.R., Montgomery, G.W., Medland, S.E., Gordon, S.D., Martin, N.G., Krasnow, V., Chuchalin, A., Babadjanova, G., Pantelejeva, G., Abramova, L.I., Tiganov, A.S., Polonikov, A., Khusnutdinova, E., Alda, M., Grof, P., Rouleau, G.A., Turecki, G., Laprise, C., Rivas, F., Mayoral, F., Kogevinas, M., 
Grigoroiu-Serbanescu, M., Propping, P., Becker, T., Rietschel, M., Nothen, M.M., Cichon, S., 2014. Genome-wide association study reveals two new risk loci for bipolar disorder. Nat Commun 5, 3339. Munakata, K., Iwamoto, K., Bundo, M., Kato, T., 2005. Mitochondrial DNA 3243A>G mutation and increased expression of LARS2 gene in the brains of patients with bipolar disorder and schizophrenia. Biol Psychiatry 57, 525-532.

Nivoli, A.M., Colom, F., Murru, A., Pacchiarotti, I., Castro-Loli, P., Gonzalez-Pinto, A., Fountoulakis, K.N., Vieta, E., 2011. New treatment guidelines for acute bipolar depression: a systematic review. J Affect Disord 129, 14-26.

Nugent, A.C., Milham, M.P., Bain, E.E., Mah, L., Cannon, D.M., Marrett, S., Zarate, C.A., Pine, D.S., Price, J.L., Drevets, W.C., 2006. Cortical abnormalities in bipolar disorder investigated with MRI and voxel-based morphometry. Neuroimage 30, 485-497.

Pacchiarotti, I., Bond, D.J., Baldessarini, R.J., Nolen, W.A., Grunze, H., Licht, R.W., Post, R.M., Berk, M., Goodwin, G.M., Sachs, G.S., Tondo, L., Findling, R.L., Youngstrom, E.A., Tohen, M., Undurraga, J., Gonzalez-Pinto, A., Goldberg, J.F., Yildiz, A., Altshuler, L.L., Calabrese, J.R., Mitchell, P.B., Thase, M.E., Koukopoulos, A., Colom, F., Frye, M.A., Malhi, G.S., Fountoulakis, K.N., Vazquez, G., Perlis, R.H., Ketter, T.A., Cassidy, F., Akiskal, H., Azorin, J.M., Valenti, M., Mazzei, D.H., Lafer, B., Kato, T., Mazzarini, L., Martinez-Aran, A., Parker, G., Souery, D., Ozerdem, A., McElroy, S.L., Girardi, P., Bauer, M., Yatham, L.N., Zarate, C.A., Nierenberg, A.A., Birmaher, B., Kanba, S., El-Mallakh, R.S., Serretti, A., Rihmer, Z., Young, A.H., Kotzalidis, G.D., MacQueen, G.M., Bowden, C.L., Ghaemi, S.N., LopezJaramillo, C., Rybakowski, J., Ha, K., Perugi, G., Kasper, S., Amsterdam, J.D., Hirschfeld, R.M., Kapczinski, F., Vieta, E., 2013. The International Society for Bipolar Disorders (ISBD) task force report on antidepressant use in bipolar disorders. Am J Psychiatry 170, 1249-1262.

Pacchiarotti, I., Valenti, M., Bonnin, C.M., Rosa, A.R., Murru, A., Kotzalidis, G.D., Nivoli, A.M., SanchezMoreno, J., Vieta, E., Colom, F., 2011. Factors associated with initial treatment response with antidepressants in bipolar disorder. Eur Neuropsychopharmacol 21, 362-369.

Pena, C.J., Bagot, R.C., Labonte, B., Nestler, E.J., 2014. Epigenetic Signaling in Psychiatric Disorders. J Mol Biol.

Perlis, R.H., 2011. Translating biomarkers to clinical practice. Mol Psychiatry 16, 1076-1087.

Perlis, R.H., Smoller, J.W., Ferreira, M.A., McQuillin, A., Bass, N., Lawrence, J., Sachs, G.S., Nimgaonkar, V., Scolnick, E.M., Gurling, H., Sklar, P., Purcell, S., 2009. A genomewide association study of response to lithium for prevention of recurrence in bipolar disorder. Am J Psychiatry 166, 718-725.

Perlis, R.H., Uher, R., Ostacher, M., Goldberg, J.F., Trivedi, M.H., Rush, A.J., Fava, M., 2011. Association between bipolar spectrum features and treatment outcomes in outpatients with major depressive disorder. Arch Gen Psychiatry 68, 351-360.

Pizzagalli, D.A., Holmes, A.J., Dillon, D.G., Goetz, E.L., Birk, J.L., Bogdan, R., Dougherty, D.D., losifescu, D.V., Rauch, S.L., Fava, M., 2009. Reduced caudate and nucleus accumbens response to rewards in unmedicated individuals with major depressive disorder. Am J Psychiatry 166, 702-710.

Popovic, D., Reinares, M., Goikolea, J.M., Bonnin, C.M., Gonzalez-Pinto, A., Vieta, E., 2012. Polarity index of pharmacological agents used for maintenance treatment of bipolar disorder. Eur Neuropsychopharmacol 22, 339-346.

Popovic, D., Reinares, M., Scott, J., Nivoli, A., Murru, A., Pacchiarotti, I., Vieta, E., Colom, F., 2013. Polarity index of psychological interventions in maintenance treatment of bipolar disorder. Psychother Psychosom 82, 292-298.

Rangel, A., Camerer, C., Montague, P.R., 2008. A framework for studying the neurobiology of valuebased decision making. Nat Rev Neurosci 9, 545-556.

Reinares, M., Sanchez-Moreno, J., Fountoulakis, K.N., 2014. Psychosocial interventions in bipolar disorder: what, for whom, and when. J Affect Disord 156, 46-55.

Robins, E., Guze, S.B., 1970. Establishment of Diagnostic Validity in Psychiatrc Illness: Its Application to Schizophrenia. Am J Psychiatry 126, 983-987.

Salehi, B., Preuss, N., van der Veen, J.W., Shen, J., Neumeister, A., Drevets, W.C., Hodgkinson, C., Goldman, D., Wendland, J.R., Singleton, A., Gibbs, J.R., Cookson, M.R., Hasler, G., 2013. Age- 
modulated association between prefrontal NAA and the BDNF gene. Int J Neuropsychopharmacol 16, $1185-1193$.

Salvadore, G., van der Veen, J.W., Zhang, Y., Marenco, S., Machado-Vieira, R., Baumann, J., Ibrahim, L.A., Luckenbaugh, D.A., Shen, J., Drevets, W.C., Zarate, C.A., Jr., 2012. An investigation of amino-acid neurotransmitters as potential predictors of clinical improvement to ketamine in depression. Int J Neuropsychopharmacol 15, 1063-1072.

Samalin, L., Guillaume, S., Courtet, P., Abbar, M., Lancrenon, S., Llorca, P.M., 2013. Methodological differences between pharmacological treatment guidelines for bipolar disorder: what to do for the clinicians? Compr Psychiatry 54, 309-320.

Schultz, W., 2006. Behavioral theories and the neurophysiology of reward. Annu Rev Psychol 57, 87115.

Schumann, G., Binder, E.B., Holte, A., de Kloet, E.R., Oedegaard, K.J., Robbins, T.W., Walker-Tilley, T.R., Bitter, I., Brown, V.J., Buitelaar, J., Ciccocioppo, R., Cools, R., Escera, C., Fleischhacker, W., Flor, H., Frith, C.D., Heinz, A., Johnsen, E., Kirschbaum, C., Klingberg, T., Lesch, K.P., Lewis, S., Maier, W., Mann, K., Martinot, J.L., Meyer-Lindenberg, A., Muller, C.P., Muller, W.E., Nutt, D.J., Persico, A., Perugi, G., Pessiglione, M., Preuss, U.W., Roiser, J.P., Rossini, P.M., Rybakowski, J.K., Sandi, C., Stephan, K.E., Undurraga, J., Vieta, E., van der Wee, N., Wykes, T., Haro, J.M., Wittchen, H.U., 2014. Stratified medicine for mental disorders. Eur Neuropsychopharmacol 24, 5-50.

Serretti, A., Artioli, P., Lorenzi, C., Pirovano, A., Tubazio, V., Zanardi, R., 2004. The C(-1019)G polymorphism of the $5-\mathrm{HT} 1 \mathrm{~A}$ gene promoter and antidepressant response in mood disorders: preliminary findings. Int J Neuropsychopharmacol 7, 453-460.

Severino, G., Squassina, A., Costa, M., Pisanu, C., Calza, S., Alda, M., Del Zompo, M., Manchia, M., 2013. Pharmacogenomics of bipolar disorder. Pharmacogenomics 14, 655-674.

Simpson, S.G., McMahon, F.J., McInnis, M.G., MacKinnon, D.F., Edwin, D., Folstein, S.E., DePaulo, J.R., 2002. Diagnostic reliability of bipolar II disorder. Arch Gen Psychiatry 59, 736-740.

Snitz, B.E., Macdonald, A.W., 3rd, Carter, C.S., 2006. Cognitive deficits in unaffected first-degree relatives of schizophrenia patients: a meta-analytic review of putative endophenotypes. Schizophr Bull 32, 179-194.

Snyder, J.S., Soumier, A., Brewer, M., Pickel, J., Cameron, H.A., 2011. Adult hippocampal neurogenesis buffers stress responses and depressive behaviour. Nature 476, 458-461.

Sole, B., Bonnin, C.M., Mayoral, M., Amann, B.L., Torres, I., Gonzalez-Pinto, A., Jimenez, E., Crespo, J.M., Colom, F., Tabares-Seisdedos, R., Reinares, M., Ayuso-Mateos, J.L., Soria, S., Garcia-Portilla, M.P., Ibanez, A., Vieta, E., Martinez-Aran, A., Torrent, C., the, C.F.R.G., 2014. Functional remediation for patients with bipolar II disorder: Improvement of functioning and subsyndromal symptoms. Eur Neuropsychopharmacol.

Stork, C., Renshaw, P.F., 2005. Mitochondrial dysfunction in bipolar disorder: evidence from magnetic resonance spectroscopy research. Mol Psychiatry 10, 900-919.

Stoy, M., Schlagenhauf, F., Sterzer, P., Bermpohl, F., Hagele, C., Suchotzki, K., Schmack, K., Wrase, J., Ricken, R., Knutson, B., Adli, M., Bauer, M., Heinz, A., Strohle, A., 2012. Hyporeactivity of ventral striatum towards incentive stimuli in unmedicated depressed patients normalizes after treatment with escitalopram. J Psychopharmacol 26, 677-688.

Sullivan, P.F., Daly, M.J., O'Donovan, M., 2012. Genetic architectures of psychiatric disorders: the emerging picture and its implications. Nat Rev Genet 13, 537-551.

Swartz, H.A., Fagiolini, A., 2012. Cardiovascular disease and bipolar disorder: risk and clinical implications. J Clin Psychiatry 73, 1563-1565.

Taylor, V., MacQueen, G., 2006. Associations between bipolar disorder and metabolic syndrome: A review. J Clin Psychiatry 67, 1034-1041.

Torrent, C., Del Mar Bonnin, C., Martinez-Aran, A., Valle, J., Amann, B.L., Gonzalez-Pinto, A., Crespo, J.M., Ibanez, A., Garcia-Portilla, M.P., Tabares-Seisdedos, R., Arango, C., Colom, F., Sole, B., Pacchiarotti, I., Rosa, A.R., Ayuso-Mateos, J.L., Anaya, C., Fernandez, P., Landin-Romero, R., AlonsoLana, S., Ortiz-Gil, J., Segura, B., Barbeito, S., Vega, P., Fernandez, M., Ugarte, A., Subira, M., Cerrillo, E., Custal, N., Menchon, J.M., Saiz-Ruiz, J., Rodao, J.M., Isella, S., Alegria, A., Al-Halabi, S., Bobes, J., Galvan, G., Saiz, P.A., Balanza-Martinez, V., Selva, G., Fuentes-Dura, I., Correa, P., Mayoral, M., 
Chiclana, G., Merchan-Naranjo, J., Rapado-Castro, M., Salamero, M., Vieta, E., 2013. Efficacy of Functional Remediation in Bipolar Disorder: A Multicenter Randomized Controlled Study. Am J Psychiatry in press.

Turecki, G., Grof, P., Grof, E., D'Souza, V., Lebuis, L., Marineau, C., Cavazzoni, P., Duffy, A., Betard, C., Zvolsky, P., Robertson, C., Brewer, C., Hudson, T.J., Rouleau, G.A., Alda, M., 2001. Mapping susceptibility genes for bipolar disorder: a pharmacogenetic approach based on excellent response to lithium. Mol Psychiatry 6, 570-578.

Vargas, C., Lopez-Jaramillo, C., Vieta, E., 2013. A systematic literature review of resting state network--functional MRI in bipolar disorder. J Affect Disord 150, 727-735.

Vieta, E., 2014. The bipolar maze: a roadmap through translational psychopathology. Acta Psychiatr Scand 129, 323-327.

Wang, Z., Li, Z., Chen, J., Huang, J., Yuan, C., Hong, W., Yu, S., Fang, Y., 2012. Association of BDNF gene polymorphism with bipolar disorders in Han Chinese population. Genes Brain Behav 11, 524528.

Whalley, H.C., Sprooten, E., Hackett, S., Hall, L., Blackwood, D.H., Glahn, D.C., Bastin, M., Hall, J., Lawrie, S.M., Sussmann, J.E., McIntosh, A.M., 2013. Polygenic Risk and White Matter Integrity in Individuals at High Risk of Mood Disorder. Biol Psychiatry in press.

Xiao, Y., Camarillo, C., Ping, Y., Arana, T.B., Zhao, H., Thompson, P.M., Xu, C., Su, B.B., Fan, H., Ordonez, J., Wang, L., Mao, C., Zhang, Y., Cruz, D., Escamilla, M.A., Li, X., 2014. The DNA methylome and transcriptome of different brain regions in schizophrenia and bipolar disorder. PLoS One 9, e95875.

Yeo, R.A., Gangestad, S.W., Walton, E., Ehrlich, S., Pommy, J., Turner, J.A., Liu, J., Mayer, A.R., Schulz, S.C., Ho, B.C., Bustillo, J.R., Wassink, T.H., Sponheim, S.R., Morrow, E.M., Calhoun, V.D., 2014. Genetic influences on cognitive endophenotypes in schizophrenia. Schizophr Res 156, 71-75.

Zanardi, R., Serretti, A., Rossini, D., Franchini, L., Cusin, C., Lattuada, E., Dotoli, D., Smeraldi, E., 2001. Factors affecting fluvoxamine antidepressant activity: influence of pindolol and 5-HTTLPR in delusional and nondelusional depression. Biol Psychiatry 50, 323-330.

Zimmermann, P., Bruckl, T., Nocon, A., Pfister, H., Lieb, R., Wittchen, H.U., Holsboer, F., Angst, J., 2009. Heterogeneity of DSM-IV major depressive disorder as a consequence of subthreshold bipolarity. Arch Gen Psychiatry 66, 1341-1352. 
Table 1. Predictors of bipolar spectrum disorders

\section{Predictor}

- Early onset of disease

- Large number of depressive episodes

- Bipolar disorders in the family history

- Occurrence of individual maniform symptoms

- Atypical depressive symptoms

- Cyclothymic temperament 
Table 2. Clinical and biomarkers related to treatment response in bipolar disorders

\begin{tabular}{|c|c|c|}
\hline State specifier & Favorable response to & References \\
\hline $\begin{array}{l}\text { Mixed episode } \\
\text { Agitation in manic episodes } \\
\text { Severe depressive episodes } \\
\text { Mild depressive episodes } \\
\text { High suicidal risk }\end{array}$ & $\begin{array}{l}\text { Olanzapine, asenapine } \\
\text { Asenapine, loxapine, aripiprazole } \\
\text { Combination treatments } \\
\text { Psychotherapy } \\
\text { Lithium }\end{array}$ & $\begin{array}{l}\text { (Grunze and } \\
\text { Azorin, 2014; } \\
\text { Kruger et al., } \\
\text { 2005) } \\
\text { (Brown et al., } \\
\text { 2013; } \\
\text { Gonzalez et } \\
\text { al., 2013; } \\
\text { Kwentus et al., } \\
\text { 2012; } \\
\text { Mclntyre et } \\
\text { al., 2009) } \\
\text { (Geddes and } \\
\text { Miklowitz, } \\
\text { 2013) } \\
\text { (Kohler et al., } \\
\text { 2014) } \\
\text { (Baldessarini } \\
\text { et al., 2006) }\end{array}$ \\
\hline Course specifier & & \\
\hline $\begin{array}{l}\text { Predominantly manic } \\
\text { Predominantly depressive } \\
\text { Typical manic-depressive course with } \\
\text { full interepisode remission } \\
\text { Seasonal affective disorder (SAD) }\end{array}$ & $\begin{array}{l}\text { Quetiapine, lithium, olanzapine, ziprasidone, } \\
\text { aripiprazole, risperidone, caregiver group } \\
\text { psychoeducation } \\
\text { Lamotrigine, psychotherapy } \\
\text { Lithium } \\
\text { Light therapy }\end{array}$ & $\begin{array}{l}\text { (Popovic et al., } \\
\text { 2012; Popovic } \\
\text { et al., 2013) } \\
\text { (Popovic et al., } \\
\text { 2012; Popovic } \\
\text { et al., 2013) } \\
\text { (Geddes and } \\
\text { Miklowitz, } \\
\text { 2013) } \\
\text { (Golden et al., } \\
\text { 2005) }\end{array}$ \\
\hline Neuropsychological specifier & & \\
\hline $\begin{array}{l}\text { Dependent personality traits } \\
\text { High cognitive functioning } \\
\text { Low cognitive functioning }\end{array}$ & $\begin{array}{l}\text { Highly structured behavioral therapy } \\
\text { Cognitive behavioral therapy (CBT) } \\
\text { Functional remediation }\end{array}$ & $\begin{array}{l}\text { (Grawe, 2004) } \\
\text { (Geddes and } \\
\text { Miklowitz, } \\
\text { 2013; Reinares } \\
\text { et al., 2014) } \\
\text { (Geddes and } \\
\text { Miklowitz, } \\
\text { 2013; Reinares } \\
\text { et al., 2014) }\end{array}$ \\
\hline
\end{tabular}




\begin{tabular}{|c|c|c|}
\hline Stage of illness & & \\
\hline $\begin{array}{l}\text { Early states } \\
\text { Late states }\end{array}$ & $\begin{array}{l}\text { Psychotherapy, psychoeducation, medication } \\
\text { Cognitive and functional remediation, social work }\end{array}$ & $\begin{array}{l}\text { (Reinares et } \\
\text { al., 2014) } \\
\text { (Reinares et } \\
\text { al., 2014) }\end{array}$ \\
\hline \multicolumn{3}{|l|}{ Imaging biomarkers } \\
\hline $\begin{array}{l}\text { Hyperactivity in limbic brain regions } \\
\text { Low activity in limbic brain regions } \\
\text { White matter hyperintensity } \\
\text { Gray matter volume reductions }\end{array}$ & $\begin{array}{l}\text { Antidepressants, deep brain stimulation } \\
\text { Thyroid hormones (uncertain) } \\
\text { Lithium } \\
\text { Lithium }\end{array}$ & $\begin{array}{l}\text { (Chen et al., } \\
\text { 2007; } \\
\text { Mayberg et } \\
\text { al., 1997; } \\
\text { Mayberg et } \\
\text { al., 2005) } \\
\\
\text { (Kato et al., } \\
\text { 2000) } \\
\text { (Chiu et al., } \\
\text { 2013; Moore } \\
\text { et al., 2009) }\end{array}$ \\
\hline \multicolumn{3}{|l|}{ Genetic markers } \\
\hline $\begin{array}{l}\text { XBP1, G allele of rs2269577 } \\
\text { BDNF, Met allele of rs6265 } \\
\text { 5-HTTPLR, I allele } \\
\text { HTR1A, CC genotype of rs6295 }\end{array}$ & $\begin{array}{l}\text { Valproic acid } \\
\text { Lithium } \\
\text { SSRI co-medication } \\
\text { Fluvoxamine co-medication }\end{array}$ & $\begin{array}{l}\text { (Kim et al., } \\
2009) \\
\text { (Wang et al., } \\
2012) \\
\text { (Zanardi et al., } \\
2001 \text { ) } \\
\text { (Serretti et al., } \\
2004)\end{array}$ \\
\hline
\end{tabular}

